\title{
DOES ORGANIC SPROUTED WHOLE WHEAT GRAIN FLOURLESS BREAD DECREASES DNA DAMAGE IN DIABETIC PATIENTS?
}

\author{
Milan RAJKOVIC ${ }^{1 *}$, Uros GLAVINIC ${ }^{1}$, Marko RISTANIC ${ }^{1}$, Milivoje COSIC ${ }^{2}$, \\ Vesna DIMITRIJEVIC-SRECKOVIC ${ }^{3}$, Iva ILIC $^{4}$, Ninoslav DJELIC ${ }^{1}$ \\ ${ }^{1}$ Department of Biology, Faculty of Veterinary Medicine, University of Belgrade, Bul. Oslobodjenja \\ 18, Belgrade, Serbia; ${ }^{2}$ Department of Animal Breeding, Faculty of Agriculture, University of Bijeljina, \\ Pavlovica put bb, Bijeljina, Bosnia and Herzegovina; ${ }^{3}$ Clinic for Endocrinology, Diabetes and Metabolic \\ Diseases, Clinical Center of Serbia, School of Medicine, University of Blegrade, Doktora Subotica 13, \\ Belgrade, Serbia; "Institute of Public Health of Serbia "Dr Milan Jovanovic Batut", Belgrade, Serbia
}

(Received 17 March, Accepted 18 August 2021)

\begin{abstract}
Diabetes is one of the main health concerns, especially in developed countries. During the last few decades, the percentage of diabetic persons is constantly increasing. Although the genetic factors have a strong influence in the development of diabetes, environmental influence (physical inactivity, inadequate nutrition leading to obesity) also have an important impact. The main objective of this investigation was to evaluate the possible influence of organic sprouted whole wheat grain flourless bread Tonus ${ }^{\circledR}$ (product of Trivit, Becej, Serbia) on DNA damage at various stages of progression through type 2 diabetes mellitus (T2DM). In addition to control (non-diabetic) subjects we analyzed obese, pre-diabetic and diabetic patients, for a total of four experimental groups. All subjects used to eat Mediterranean diet for at least two years before being included in our study. In each of four groups we had five persons practicing the Mediterranean diet but instead of bread they consumed flourless bread Tonus ${ }^{\mathbb{Q}}$. The DNA damage was evaluated on peripheral blood mononuclear cells by alkaline single cell gel electrophoresis (Comet) assay at the very beginning (before starting the Tonus ${ }^{\circledR}$ bread diet), and after exactly the three months of consumption of Tonus ${ }^{\circledR}$ bread. Statistical analysis revealed that only in patients with type 2 diabetes, Tonus ${ }^{\circledR}$ bread intake led to decreased DNA damage compared to the level of DNA damage of these patients before they started Tonus ${ }^{\circledR}$ bread diet. We assume that decrease of body weight and hyperinsulinemia caused by Tonus ${ }^{\circledR}$ bread in the diet might be one of the main causes of decreased DNA damage.
\end{abstract}

Key words: diabetes, nutrition, flourless bread, DNA damage, Comet assay

\footnotetext{
*Corresponding author: e-mail: mrajkovic@vet.bg.ac.rs
} 


\section{INTRODUCTION}

The obesity and diabetes mellitus type 2 (T2DM) are constantly increasing worldwide, especially in developed countries [1]. Global climate changes, environmental pollution and use of chemical additives in all human activities, lead to disturbances in the ecosystem and food production [2]. Changes in lifestyle, especially in diet habits, have caused epidemics of obesity during last decades. Furthermore, the consumption of food of animal origin has been steadily increasing in the recent decades, which additionally could contribute to human metabolic disorders, having in mind the potential of hormone residues in animal food products [3]. One of the highly esteemed foodstuff in human diet is cow's milk which contains essential nutrients, including proteins, carbohydrates, minerals and vitamins, however intake of certain types of milk proteins can lead to endocrine disorders, such as diabetes [4]. Obesity is very often accompanied by endocrine and cardiovascular disturbances [5]. During the period from the year 1980 till 2008, the number of people diagnosed with diabetes ( $90 \%$ of that are T2DM) increased from 153 million to 347 million [1]. From an epidemiological point of view, obesity is an important risk factor of the metabolic syndrome. Apart from obesity, metabolic syndrome is characterized by insulin resistance which may lead to arterial hypertension, hyperlipidemia, hyperinsulinemia and increase of glycaemia [6-8]. Diabetes occurs as a consequence of these disturbances. There are two main kinds of diabetes: type 1 (insulin-dependent diabetes mellitus) and type 2 (insulin independent diabetes mellitus). Both types have systemic disturbance in regulation of blood sugar concentration. In diabetes mellitus type 1 (DMT1) the pancreas is not producing enough of insulin, while in DMT2 there is enough insulin but the reactivity of tissues/receptors to insulin is lowered or completely absent $[9,10]$. Reactive oxygen species (ROS) and reactive nitrogen species (RNS) play an important role in the pathogenesis of insulin-dependent diabetes because they induce oxidative stress. Various cells in the human body are permanently exposed to the effects of ROS created in the processes of oxidative catabolism in the mitochondria or during different redox cycles [11]. At physiological level, free radicals are created and very quickly neutralized by enzymatic and non-enzymatic mechanisms [12]. However, the normal functions of cells are disturbed in the metabolic syndrome. Also, antioxidative defense systems are weakened in metabolic syndrome leading to accumulation of large quantities of ROS which causes damage to cell organelles and nucleic acids, so in the long run the cell death (apoptosis) may ocurr [13]. Many clinical studies point that it is necessary to use antioxidant substances in order to mitigate the harmful effects of ROS to the cells. During the last years, there were different investigations on the influence of various diets to the human health [14]. Human nutrition investigations today, are focused on the concept of the full diet instead on particular components of food items. Diets with ultra-processed components consumed in large amounts, such as additives or margarine with fitosterols, do not lead to long term improvement of human health, nor to the decrease of risk for chronic diseases. In contrast, these diets can increase the occurrence of some chronic diseases [15]. 
The Mediterranean diet was described for the first time during the 1960-ies by Ancel Keys [16]. This diet is based on various food intakes, mainly of plant origin. The percentage of fat in this diet should be about $30 \%$ and not more than $40 \% \quad[16,17]$. The main part of the diet are fruits and vegetables, then leguminoses, cereals, olive oil, and very little amounts of animal origin food [18,19]. Previous epidemiological studies have shown that high intake of fruits and vegetables lowers the risk of diabetes mellitus development. Various components of the Mediterranean diet have a high content of antioxidant substances which significantly decrease insulin resistance in patients with the metabolic syndrome [20]. The dietary fibers present in sufficient amounts in the bread have a very important role in control of diabetes. The recommended daily intake of fibers is $25-30 \mathrm{~g}$. It is assumed that soluble fibers play very important role in the metabolism of fats and glucose [21].

In our investigation we explored the influence of 3 months of consumption of sprouted whole grain flourless bread "Tonus" (Trivit d.o.o., Bečej, Serbia) in combination with Mediterranean diet on the level of DNA damage in the Comet assay. According to the available literature data, influence of sprouted whole grain flourless bread was not investigated on diabetes and oxidative stress in humans.

The main objective of this investigation was to evaluate influence of organic sprouted whole grain flourless bread Tonus ${ }^{\circledR}$ (product of Trivit, Becej, Serbia) on DNA damage at various stages of progression through type 2 diabetes mellitus.

\section{MATERIALS AND METHODS}

\section{Ethics statement}

All participants gave a written consent to participate in this investigation, and it was also approved by the Ethical Committee of Serbian Medical Society, Belgrade.

\section{Subjects}

In this study, 20 women were included, divided into four equal experimental groups. We chose women because they were much more prevalent in comparison to men among unhealthy subjects. The first group comprised healthy subjects, the second obese, third one prediabetics and in the fourth group we included persons with T2DM. In these investigations we included only women on the Mediterranean type of diet, full in complex carbohydrates and dietary fibers originating from fruits, vegetables and cereals, olive oil, blue sea fish and with moderate intake of diary and meat products. All patients consumed the flourless bread Tonus during the three months (Trivit Group, d.o.o., Bečej, Serbia) in the amount of $170 \mathrm{~g}$ daily, instead of the other kind of bread they used to have during their meals. The Comet assay was performed before the diet with Tonus bread, and also after three months of this diet. We chose the three month period because it turned out to be long enough to obtain some effects, and the investigated subjects may have been less motivated if the duration of the study was longer. 


\section{Sampling and cell preparation}

Blood samples were withdrawn by venipuncture from female donors. All samples within one group were taken on the same day, and all tested parameters were done on fresh samples. The blood was diluted (1:1) with RPMI medium, underlaid with Histopaque 1077 and centrifuged at $1900 \mathrm{~g}$ for $15 \mathrm{~min}$. The peripheral blood mononuclear cells (PBMC) layer (buffy coat) was washed twice in RPMI 1640 medium, each wash was followed by centrifugation for $10 \mathrm{~min}$ at $1800 \mathrm{~g}$.

\section{The Comet assay}

The alkaline version of Comet assay was performed according to Singh et al. [22] and Tice et al. [23] with minor modifications. Briefly, the cell viability was checked by Trypan blue exclusion [24]. A $100 \mu \mathrm{L}$ of cell suspension was mixed with $100 \mu \mathrm{L}$ of $1 \%$ low melting point agarose (LMPA). $90 \mu \mathrm{L}$ of suspension was casted on a microscope slide precoated with $1 \%$ normal melting agarose and put in the fridge to solidify. Then the slides were immersed in cold lysis solution at pH $10(2.5 \mathrm{M} \mathrm{NaCl}, 100 \mathrm{mM}$ EDTA, $10 \mathrm{mM}$ Tris $\mathrm{pH} \mathrm{10,1 \%}$ Triton $\mathrm{X}-100,10 \%$ DMSO) overnight at $4{ }^{\circ} \mathrm{C}$. After lysis, slides were placed in a horizontal gel electrophoresis tank to allow DNA unwinding in cold electrophoresis buffer $(300 \mathrm{mM} \mathrm{NaOH}, 1 \mathrm{mM}$ EDTA, $\mathrm{pH}>13)$ for $30 \mathrm{~min}$. Electrophoresis was carried out at $4{ }^{\circ} \mathrm{C}$ with electric current of $25 \mathrm{~V}(1.1 \mathrm{~V} / \mathrm{cm})$ for 30 $\mathrm{min}$. The slides were then removed from the tray and washed with neutralizing buffer (0.4 M Tris $\mathrm{HCl}, \mathrm{pH} 7.5)$ for $5 \mathrm{~min}$. The neutralization was repeated three times. Finally, the slides were fixed with ice cold methanol, dried and stored. Before analysis, the slides were rehydrated with ice cold distilled water and stained with ethidium bromide $(20 \mu \mathrm{g} / \mathrm{mL})$. The slides were examined under a fluorescence microscope (AxioImager Z1, Carl Zeiss; excitation filter, 515-560 nm; emission filter, $590 \mathrm{~nm}$ ). Comet were scored visually as described by Anderson et al. [25] and expressed as the total comet score (TCS) according to Collins [26]. In visual scoring the estimated level of DNA damage results in five classes of comets: (A) no damage, $<5 \%$; (B) low level damage, 5-20\%; (C) medium level damage, 20-40\%; (D) high level damage, 40-95\%; (E) total damage, $>95 \%$ (,hedgehogs comets“) (Figure 1). TCS is calculated according to the formula: TCS $=1 \times \mathrm{B}+2 \times \mathrm{C}+3 \times \mathrm{D}+4 \times \mathrm{E}$, where $\mathrm{B}$ to $\mathrm{E}$ represents percentage of cells with various level of DNA damage.

\section{Statistical analysis}

Given that the data about TCS were heterogeneous (Coefficient of variation $>30 \%$ ), the transformation $y=x+50$ was applied to all data. Groups were compared using twoway ANOVA with repeated measures in one factor followed by Tukey's or Sidak's post hoc test. Untransformed data are presented as mean \pm standard deviation (Mean \pm SD). Significant difference was estimated with $\mathrm{p}<0.05, \mathrm{p}<0.01, \mathrm{p}<0.001$ and $\mathrm{p}<0.0001$ significance levels. Statistical analysis of the results obtained in the experiment was carried out using statistical software GraphPad Prism version 6 (GraphPad, San Diego, CA, USA). 


\section{RESULTS}

The basic characteristics of each group before the start of the experiment, and after 3 months of flourless bread consumption are shown in Table 1 and Table 2. Among various biochemical and morphometric characteristics only the fasting plasma glucose (denoted as glycaemia) was significantly decreased in obese and T2DM subjects after three months of Tonus bread consumption. The results of DNA damage analysis are presented using TCS as a parameter. As presented in Table 3, the results of TCS before the diet with Tonus bread were: $89.00 \pm 34.37$ in healthy controls $72.80 \pm 29.58$ in obese patients, $98.80 \pm 40.33$ in prediabetics and $117.40 \pm 48.710$ in newly diagnostified T2DM. After the three months on Tonus bread diet we observed the following results of TCS (Table 3): 76.00 \pm 35.34 in healthy controls, $62.60 \pm 14.77$ in obese, $73.00 \pm 17.13$ in prediabetics and $77.40 \pm 19.99$ in T2DM patients. Therefore, in our investigations we obtained results which show that a diet with flourless bread in combination with the Mediterranean diet manifested with a significant $(\mathrm{P}<0.01)$ decrease of DNA damage in patients with newly diagnostified T2DM. In control group TCS was lowered by $14.6 \%$ after the investigated diet, in a group of obese patients it was lowered by $14 \%$, and in prediabetics it was $26 \%$. However, the decrease in all these groups was not statistically significant. Only in a group of T2DM patients we observed profound and statistically significant decrease of TCS for $66 \%$ (Figure 1).

Table 1. Basic characteristics of the study groups before Tonus bread consummation

\begin{tabular}{lcccc}
\hline Parameters & Normal & Obese & Prediabetics & T2DM de novo \\
\hline Age (years) & $52.80 \pm 12.7$ & $49.00 \pm 11.00$ & $59.80 \pm 13.70$ & $67.40 \pm 5.32$ \\
Glycemia & $5.20 \pm 0.55$ & $5.04 \pm 0.68$ & $5.70 \pm 0.54$ & $5.62 \pm 0.36$ \\
HbA1c $(\%)$ & $5.35 \pm 0.13$ & $5.30 \pm 0.20$ & $5.52 \pm 0.36$ & $5.93 \pm 0.36$ \\
Waist circumference $(\mathrm{cm})$ & $76.50 \pm 7.14$ & $92.00 \pm 11.37$ & $95.6 \pm 12.26$ & $93.00 \pm 7.16$ \\
BMI $\left(\mathrm{kg} / \mathrm{m}^{2}\right)$ & $22.10 \pm 0.82$ & $30.36 \pm 2.60$ & $32.28 \pm 5.85$ & $32.72 \pm 4.97$ \\
HDL cholesterol & $1.82 \pm 0.22$ & $1.24 \pm 0.18$ & $1.71 \pm 0.38$ & $1.26 \pm 0.18$ \\
Triglycerides & $0.89 \pm 0.15$ & $1.21 \pm 0.41$ & $1.82 \pm 1.41$ & $2.15 \pm 0.45$ \\
Systolic BP $(\mathrm{mmHg})$ & $116.67 \pm 11.55$ & $120.00 \pm 0.00$ & $130.00 \pm 22.36$ & $120.67 \pm 4.04$ \\
Diastolic BP $(\mathrm{mmHg})$ & $73.33 \pm 5.77$ & $80.00 \pm 0.00$ & $65.00 \pm 32.79$ & $73.00 \pm 7.55$ \\
\hline
\end{tabular}

The results are presented as mean \pm SE; BMI - body mass index; HDL-high density lipoprotein; BP- blood pressure. There were no statistically significant differences among groups for any analysed parameter $(p>0.05$ in one-way Kruskal-Wallis and Monte Carlo test). 
Table 2. Basic characteristics of the study groups after Tonus bread consumption

\begin{tabular}{lcccc}
\hline Parameters & Normal & Obese & Prediabetics & T2DM de novo \\
\hline Age (years) & $52.80 \pm 12.7$ & $49.00 \pm 11.00$ & $59.80 \pm 13.70$ & $67.40 \pm 5.32$ \\
Glycemia & $5.12 \pm 0.64$ & $4.38 \pm 0.53^{* *}$ & $4.97 \pm 0.26$ & $4.42 \pm 0.43^{* *}$ \\
HbA1c $(\%)$ & $5.30 \pm 0.10$ & $5.20 \pm 0.14$ & $5.60 \pm 0.16$ & $5.86 \pm 0.36$ \\
Waist circumference $(\mathrm{cm})$ & $76.60 \pm 6.86$ & $98.33 \pm 11.93$ & $96.25 \pm 15.84$ & $94.60 \pm 5.27$ \\
BMI & $22.31 \pm 1.31$ & $31.50 \pm 3.28$ & $31.60 \pm 5.96$ & $32.00 \pm 4.67$ \\
HDL cholesterol & $1.71 \pm 0.16$ & $1.13 \pm 0.23$ & $1.76 \pm 0.32$ & $1.33 \pm 0.23$ \\
Triglycerides & $0.76 \pm 0.21$ & $1.13 \pm 0.45$ & $1.31 \pm 0.32$ & $1.81 \pm 0.23$ \\
Systolic BP (mmHg) & $122.50 \pm 18.93$ & $130.00 \pm 14.14$ & $126.67 \pm 23.09$ & $125.00 \pm 4.08$ \\
Diastolic BP (mmHg) & $79.00 \pm 12.27$ & $77.50 \pm 3.54$ & $68.33 \pm 10.58$ & $79.00 \pm 1.73$ \\
\hline
\end{tabular}

The results are presented as mean $\pm \mathrm{SE}$; BMI - body mass index; BH- body height; BMI - body mass index; BP- blood pressure. There were no statistically significant differences among groups for any analysed parameter $(p>0.05$ in one-way Kruskal-Wallis and Monte Carlo test), the value of glycemia is significantly $(p>0.01)$ decreased in groups of obese and diabetic patients (ANOVA test).

Table 3. The distribution of comet classes (0-4) according to Anderson et al. (22) in four groups of subjects before anf after the Tonus bread consumption

\begin{tabular}{|c|c|c|c|c|}
\hline Groups & $\begin{array}{c}\text { Upisati } \\
\text { naziv }\end{array}$ & $\begin{array}{c}\text { TCS before } \\
\text { consumption }\end{array}$ & $\begin{array}{c}\text { TCS after } 3 \text { months of flourless } \\
\text { bread consumption }\end{array}$ & Significance \\
\hline \multirow{5}{*}{ Normal } & 0 & 48.20 & 53.50 & \multirow{5}{*}{$\mathrm{p}>0.05$} \\
\hline & 1 & 30.40 & 32.63 & \\
\hline & 2 & 12.00 & 9.13 & \\
\hline & 3 & 3.00 & 1.88 & \\
\hline & 4 & 6.40 & 2.88 & \\
\hline \multirow{5}{*}{ Obese } & 0 & 56.80 & 57.75 & \multirow{5}{*}{$\mathrm{p}>0.05$} \\
\hline & 1 & 24.80 & 28.75 & \\
\hline & 2 & 10.60 & 8.63 & \\
\hline & 3 & 5.00 & 3.38 & \\
\hline & 4 & 2.80 & 1.50 & \\
\hline \multirow{5}{*}{ Prediabetes } & 0 & 48.00 & 50.85 & \multirow{5}{*}{$\mathrm{p}>0.05$} \\
\hline & 1 & 25.60 & 30.23 & \\
\hline & 2 & 12.00 & 13.56 & \\
\hline & 3 & 8.40 & 4.10 & \\
\hline & 4 & 6.00 & 1.27 & \\
\hline \multirow{5}{*}{$\mathrm{T} 2 \mathrm{DM}$} & 0 & 38.80 & 52.89 & \multirow{5}{*}{$\mathrm{p}<0.01$} \\
\hline & 1 & 29.00 & 29.00 & \\
\hline & 2 & 14.80 & 11.00 & \\
\hline & 3 & 10.20 & 3.67 & \\
\hline & 4 & 7.20 & 3.44 & \\
\hline
\end{tabular}




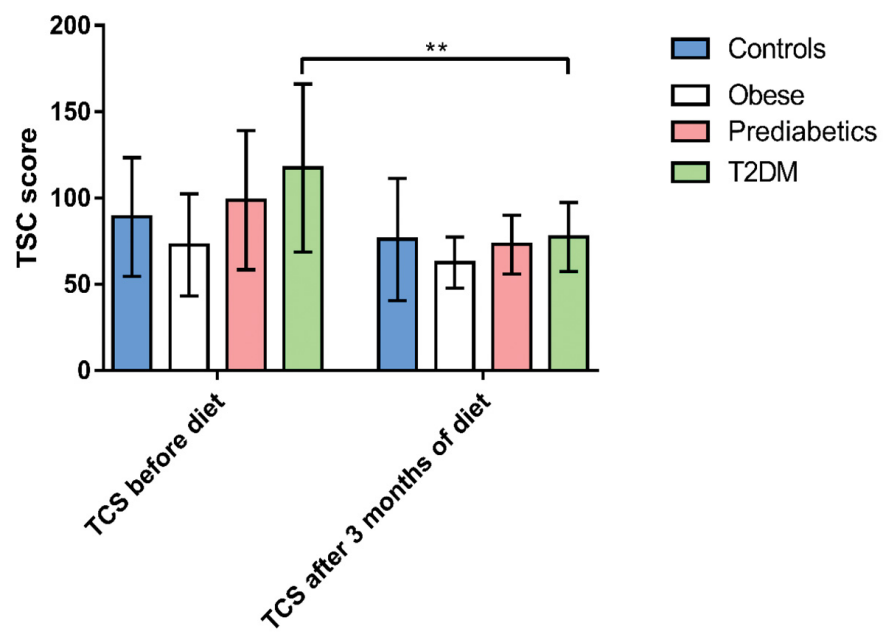

Figure 1. TCS values within groups before and after 3 months of Tonus bread consummation

\section{DISCUSSION}

The Comet assay as a genotoxicological method is used in many studies in order to find out possible genotoxic or antigenotoxic effects during various diets $[27,28]$. As far as we are aware, only a few studies were designed to examine the effects of a single grocery product on DNA damage. Spadafranca et al. [29] investigated the effects of chocolate at DNA damage level, while Ibero-Baraibar et al. [30] evaluated the effects of cocoa extract. Our study of possible antigenotoxic effects of flourless bread within a Mediterranean diet is the first one using patients at various stages of the development of T2DM. Oxidative stress and inflammation strongly influence the development of the metabolic syndrome, which very often includes diabetes mellitus. Nutritional stress caused with food rich in fat and carbohydrates potentiate the negative influence of ROS through increased lipid peroxidation and protein carbonilation, along with the existing decrease in antioxidative defense in obese people [31]. Chronic oxidative stress in obese persons is one of the most important contributing factors to the development of various pathological conditions such as insulin resistance, diabetes and cardiovascular diseases. Nutrition with higher amounts of dietary fibers is an important factor in diabetes control. Consumption of food rich in dietary fibers can help in body mass regulation, through intrinsic effects, as well as through hormonal response of the organism [17]. Experimental studies have shown that intake of food rich in fibers decreases the feeling of being hungry and supports the feeling of being satiated, in comparison to food with poor fiber content [32]. Cereals are one of the best sources of dietary fibers [33]. Cereals contain a significant concentration of antioxidative compounds which can contribute to antioxidative defense of an organism, as proven in various investigations [34]. De Munter et al. [35] have shown that increased intake 
of dietary fibers from cereals significantly lower the risk of T2DM development. In the present investigation, DNA damage was decreased in all groups of subjects after the three months of Tonus flourless bread consumption. However, only in a group of T2DM patients this decrease was statistically significant $(\mathrm{p}<0.01)$. This finding is in accordance to Shetty et al. [13] who found that in metabolic syndrome (including diabetes mellitus) consumption of food rich in antioxidants can mitigate the disturbed antioxidative defense and decrease harmful effects of ROS. Würsch and Pi-Sunyer [33] revealed that a daily intake of only $3 \mathrm{~g}$ of $10 \% \beta$-glucan fiber which is present in cereals, causes a decrease of glucose peak for $50 \%$ and a significant decrease of plasma LDL cholesterol. The decrease of lipid concentration is accompanied by lower negative influence of ROS on cells, including the lower DNA damage. Pick et al. [21] confirmed that consumption of oat bran bread helps in control of glycaemia and blood fat concentrations in comparison to nutrition with white bread. Results of this investigation have shown that after three months of Tonus bread consumation glycaemia and trigliciridemia are lowered in patients with prediabetes and T2DM, but this did not reach statistical significance. On the other hand, obese and T2DM patients had statistically significant $(\mathrm{P}<0.01)$ fasting plasma glucose (Tables 1 and 2$)$. In our investigation, we have also shown that flourless bread exhibited good antioxidative effects in comparison to white bread. In an experiment with hypocaloric diet with addition of cocoa extract, there were no significant differences between consumption of flourless bread and the group using the extract and the control group without the extract a supplement [30]. On the other hand, we observed a significant decrease of DNA damage only in patients with newly diagnosed T2DM after 3 months of flourless bread in the diet. The observed decreased of DNA damage possibly resulted from reduction of body weight, better glycaemia control, lower insulinemia and decrease of ROS which are capable to cause DNA damage. Our findings are in accordance to the investigation of Othman et al. [36] that pathophysiological concentrations of insulin induce DNA damage in human peripheral blood lymphocytes and human colon adenocarcinoma cells (HT29) in culture. Insulin induced ROS production as examined by the oxidation of the dyes 2',7'-dichlorodihydrofluorescein diacetate (H2DCF-DA) and dihydroethidium (DHE). The radical scavenger tempol protected these cells from oxidative damage. In addition, Othman et al. [36] revealed that insulin-induced stimulation of oxidative metabolism in the mitochondria is the main source of ROS. Soares et al. [37] have found that decrease of body mass due to a specific diet, reduced calorie intake, reduced consumption of carbohydrates and proteins, and decreased level of cholesterol and $\mathrm{Na}^{+}$in body fluids leads to statistically significant decrease of DNA damage. Also, Schröder [17] led the epidemiological study supporting the protective effects of Mediterranean diet on body mass regulation and prevention of diabetes in humans. Moreover, in patients with diagnostified T2DM higher intake of fresh vegetables and fruits decreases the oxidative stress and inflammation [38]. 


\section{CONCLUSIONS}

The Mediterranean diet in combination with organic sprouted whole grain flourless bread made of cereals rich in fibers will cause better regulation of body mass, glycaemia and insulinemia, as well as improvement of overall medical condition in patients with diabetes. Moreover, the results of present investigation point at the need of Mediterranean diet rich in vegetables, fruits and dietary fibers in order to control glycaemia/insulinemia in patients with diagnostified T2DM, as well as in people at risk for the development of diabetes.

\section{Acknowledgements}

This study was supported by the Ministry of Education, Science and Technological Development of the Republic of Serbia through the Grant No. III46002 for a project led by Professor Zoran Stanimirovic, and Contract number 451-03-68/2020$14 / 200143$ and Innovative voucher number 248 (Innovation Fund of the Republic of Serbia, Principal Investigator Prof. Ninoslav Djelic).

\section{Authors' contributions}

MŽR, UG, MĐR and II carried out the sample collection, experimental work and participated in drafting the manuscript. MŽR, UG and MĐR participated in the design of the study and performed the statistical analysis. NĐ, MĆ and VSD helped in drafting the manuscript. All authors read and approved the final manuscript.

\section{Declaration of conflicting interests}

The author(s) declared no potential conflicts of interest with respect to the research, authorship, and/or publication of this article.

\section{REFERENCES}

1. Hartstra AV, Bouter KE, Bäckhed F, Nieuwdorp M: Insights into the role of the microbiome in obesity and type 2 diabetes. Diabetes care 2015, 38:159-165.

2. Stanimirović Z, Glavinić U, Ristanić M, Aleksić N, Jovanović NM, Vejnović B, Stevanović $\mathrm{J}$ : Looking for the causes of and solutions to the issue of honey bee colony losses. Acta Vet-Beograd 2019, 69 (1), 1-31.

3. Snoj T: Hormones in food as a potential risk for human reproductive and health disorders. Acta Vet-Beograd 2019, 69 (2), 137-152.

4. Ristanić M, Glavinić U, Vejnović B, Maletić M, Kirovski D, Teodorović V, Stanimirović Z: Beta-casein gene polymorphism in Serbian Holstein-Friesian cows and its relationship with milk production traits. Acta Vet-Beograd 2020, 70 (4), 497-510. 
5. Aballay LR, Eynard AR, Díaz MDP, Navarro A, Muñoz SE: Overweight and obesity: a review of their relationship to metabolic syndrome, cardiovascular disease, and cancer in South America. Nutr Rev 2013, 71:168-179.

6. Dandona P, Aljada A, Chaudhuri A, Mohanty P, Garg R: Metabolic syndrome: a comprehensive perspective based on interactions between obesity, diabetes, and inflammation. Circulation 2005, 111:1448-1454.

7. Åsgård R: Oxidative DNA damage and other risk factors, in relation to lifestyle in diabetes type II and metabolic syndrome patients. Biovetenskaper och näringslära/Biosciences and Nutrition 2008.

8. Bonomini F, Rodella LF, Rezzani R: Metabolic syndrome, aging and involvement of oxidative stress. Aging Dis 2015, 6:109.

9. Song F, Jia W, Yao Y, Hu Y, Lei L, Lin J, Sun X, Liu L: Oxidative stress, antioxidant status and DNA damage in patients with impaired glucose regulation and newly diagnosed Type 2 diabetes. Clin Sci 2007, 112:599-606.

10. Ozougwu JC, Obimba KC, Belonwu CD, Unakalamba CB: The pathogenesis and pathophysiology of type 1 and type 2 diabetes mellitus. J Physiol Pathophysiol 2013, 4:4657.

11. Møller P, Loft S: Oxidative DNA damage in human white blood cells in dietary antioxidant intervention studies. Am J Clin Nutr 2002, 76:303-310.

12. Cooke MS, Evans MD, Dizdaroglu M, Lunec J: Oxidative DNA damage: mechanisms, mutation, and disease. Faseb J 2003, 17:1195-1214.

13. Shetty S, Kumari NS, Madhu LN: Oxidative stress, antioxidant status and DNA damage in type 2 diabetes mellitus. Res J Pharm Biol Chem Sci 2013, 4:437-443.

14. Zatalia SR, Sanusi H: The role of antioxidants in the pathophysiology, complications, and management of diabetes mellitus. Acta Med Indones 2013, 45:141-147.

15. Fardet A: Towards a more holistic vision of human nutrition to prevent from diet-related chronic diseases: the reductionist drift. Int J Food Sci Nutr Diet 2016, 5:1-2.

16. Trichopoulou A, Lagiou P: Healthy traditional Mediterranean diet: an expression of culture, history, and lifestyle. Nutr Rev 1997, 55:383-389.

17. Schröder H: Protective mechanisms of the Mediterranean diet in obesity and type 2 diabetes. J Nutr Biochem 2007, 18:149-160.

18. Díez-Espino J, Buil-Cosiales P, Serrano-Martínez M, Toledo E, Salas-Salvadó J, MartínezGonzález MÁ: Adherence to the Mediterranean diet in patients with type 2 diabetes mellitus and HbA1c level. Ann Nutr Metab 2011, 58:74-78.

19. Salas-Salvadó J, Guasch-Ferré M, Lee CH, Estruch R, Clish CB, Ros E: Protective effects of the Mediterranean diet on type 2 diabetes and metabolic syndrome. J Nutr 2015, 146:920-927.

20. Georgoulis M, Kontogianni M, Yiannakouris N: Mediterranean diet and diabetes: prevention and treatment. Nutrients 2014, 6:1406-1423.

21. Pick ME, Hawrysh ZJ, Gee MI, Toth E, Garg ML, Hardin RT: Oat bran concentrate bread products improve long-term control of diabetes: a pilot study. J Am Diet Assoc 1996, 96:1254-1261.

22. Singh,NP, McCoy MT, Tice RR, Schneider EL: A simple technique for quantification of low levels of DNA damage in individual cells. Exp Cell Res 1988, 175:184-191. 
23. Tice RR, Agurell E, Anderson D, Burlinson B, Hartmann A, Kobayashi H, Miyamae Y, Rojas E, Ryu JC, Sasaki YF, Single cell gel/comet assay: Guidelines for in vitro and in vivo genetic toxicology testing. Environ Mol Mutagen 2000, 35:206-221.

24. Pool-Zobel BL, Guigas C, Klein R, Neudecker CH, Renner HW, Schmezer P: Assesment of genotoxic effects of Lindane. Food Chem Toxicol 1993, 4:271-283.

25. Anderson DYTW, Yu TW, Phillips BJ, Schmezer P: The effect of various antioxidants and other modifying agents on oxygen-radical-generated DNA damage in human lymphocytes in the COMET assay. Mutat Res 1994, 307:261-271.

26. Collins AR: The comet assay. Principles, applications, and limitations. Mol Biotechnol 2004, 26:249-261.

27. Dusinska M, Collins AR: The comet assay in human biomonitoring: gene-environment interactions. Mutagenesis 2008, 23:191-205.

28. Collins AR, Azqueta A, Langie SA: Effects of micronutrients on DNA repair. Eur J Nutr 2012, 51:261-279.

29. Spadafranca A, Martinez Conesa C, Sirini S, Testolin G: Effect of dark chocolate on plasma epicatechin levels, DNA resistance to oxidative stress and total antioxidant activity in healthy subjects. Br J Nutr 2010, 103:1008-1014.

30. Ibero-Baraibar I, Azqueta A, Lopez de Cerain A, Martinez JA, Zulet MA: Assessment of DNA damage using comet assay in middle-aged overweight/obese subjects after following a hypocaloric diet supplemented with cocoa extract. Mutagenesis 2015, 30:139-146.

31. Newsholme P, Cruzat VF, Keane KN, Carlessi R, de Bittencourt Jr PIH: Molecular mechanisms of ROS production and oxidative stress in diabetes. Biochem J 2016, 473:4527-4550.

32. Howarth NC, Saltzman E, Roberts SB: Dietary fiber and weight regulation. Nutr Rev 2001, 59:129-139.

33. Würsch P, Pi-Sunyer FX: The role of viscous soluble fiber in the metabolic control of diabetes: a review with special emphasis on cereals rich in $\beta$-glucan. Diabetes care 1997, 20:1774-1780.

34. Pellegrini N, Serafini M, Salvatore S, Del Rio D, Bianchi M, Brighenti F: Total antioxidant capacity of spices, dried fruits, nuts, pulses, cereals and sweets consumed in Italy assessed by three different in vitro assays. Mol Nutr Food Res 2006, 50:1030-1038.

35. de Munter JS, Hu FB, Spiegelman D, Franz M, van Dam RM: Whole grain, bran, and germ intake and risk of type 2 diabetes: a prospective cohort study and systematic review. PLoS Med 2007, 4:261.

36. Othman EM, Leyh A, Stopper H: Insulin mediated DNA damage in mammalian colon cells and human lymphocytes in vitro. Mutat Res 2013, 745:34- 39

37. Soares NP, dos Santos ACS, Costa EC, Azevedo GD, Damasceno DC, Fayh APT, Lemos TMAM: Diet-induced weight loss reduces DNA damage and cardiometabolic risk factors in overweight/obese women with polycystic ovary syndrome. Ann Nutr Metab 2016, 68:220-227.

38. Åsgård R, Rytter E, Basu S, Abramsson-Zetterberg L, Möller L, Vessby B: High intake of fruit and vegetables is related to low oxidative stress and inflammation in a group of patients with type 2 diabetes. Scand J Food Nutr 2007, 51:149-158. 


\title{
DA LI ORGANSKI HLEB BEZ BRAŠNA OD CELIH PROKLIJALIH ZRNA PŠENICE SMANJUJE OŠTEĆENJA DNK KOD PACIJENATA SA DIJABETESOM?
}

\author{
Milan RAJKOVIC, Uros GLAVINIC, Marko RISTANIC, Milivoje COSIC, \\ Vesna DIMITRIJEVIC-SRECKOVIC, Iva ILIC, Ninoslav DJELIC
}

Dijabetes predstavlja jedan od glavnih zdravstvenih problema, naročito u razvijenim zemljama. Tokom poslednjih nekoliko decenija neprekidno se povećava procenat osoba obolelih od dijabetesa. Mada genetički faktori imaju snažan uticaj na razvoj dijabetesa, uticaji sredine (fizička neaktivnost, nepravilna ishrana koja dovodi do gojaznosti) takođe imaju veliki uticaj na razvoj ove bolesti. Tokom nekoliko poslednjih decenija procenat osoba sa dijabetesom se konstantno povećava. Glavni cilj ovog istraživanja bio je da se proceni mogući uticaj organskog hleba bez brašna od celih proklijalih zrna pšenice, Tonus $^{\circledR}$ (Trivit, Bečej, Serbia) na oštećenja DNK u različitim stadijumima progresije kroz tip 2 dijabetes melitus. Pored kontrolne grupe (zdrave osobe), analizirali smo gojazne, predijabetičare i dijabetičare, što čini ukupno četiri eksperimentalne grupe. Sve osobe su koristile Mediteransku ishranu najmanje dve godine pre nego su uključene u ovu studiju. U svakoj grupi imali smo pet osoba koje su upražnjavale Mediteransku ishranu, ali su umesto uobičajenog hleba konzumirali hleb bez brašna Tonus ${ }^{\circledR}$. Oštećenja DNK su evaluirana alkalnom verzijom elektoroforeze DNK pojedinačnih ćelija (komet test) na samom početku (pre uvođenja hleba Tonus ${ }^{\circledR}$ u ishranu) i tačno nakon tri meseca konzumiranja hleba Tonus ${ }^{\circledR}$. Statistička analiza otkrila je da samo kod pacijenata sa dijabetesom tipa 2 konzumiranje Tonus hleba dovodi do smanjenja oštećenja DNK u poređenju sa stepenom oštećenja DNK kod ovih pacijenata pre nego su otpočeli dijetu sa hlebom Tonus. Pretpostaljamo da je pad hiperinsulinemije usled konzumiranja hleba Tonus mogao da bude jedan od glavnih uzroka smanjenja oštećenja DNK. 